\title{
Trend Analysis of Inland Fish Production of Tamil Nadu with Special References to Resources and Seed Production
}

\author{
T. Gowsalya*, V. Kanaga and B. Sundaramoorthy \\ Department of Aquaculture, Dr. M.G.R. Fisheries College and Research Institute, \\ Thalainayeru, Nagapattinam - 611 001, Tamil Nadu, India \\ *Corresponding author
}

\section{A B S T R A C T}

Inland fishery resources are significantly contributed in fisheries sectors. In this regard, trend of inland fish production of Tamil Nadu was analyzed based on the

\section{Keywords}

Inland fishery

resources,

Underutilization,

Seed production,

Fish production,

Relationship

Article Info

Accepted:

04 July 2019

Available Online:

10 August 2019 available resources and utilization and seed production for the last decade. Calculated Average Annual Growth rate of fish seed production and inland fish production were $10.21 \%$ and $1.85 \%$, respectively. The linear regression line for inland fish production was indicated that increasing trend for every year $\left(R^{2}=0.673\right)$, while fish seed production was negative trend $\left(\mathrm{R}^{2}=0.094\right)$. Also, the positive relationship was existed between fish seed production and inland fish production of Tamil Nadu, which was proved by $\mathrm{R}^{2}=0.503$. In this regard, Tamil Nadu also has vast inland fishery resources (3.83 lakhs ha.) in the form of ponds, tanks, river, reservoirs and brackish water with potential of the state is 4.5 lakhs tons but the present fish production was 2.15 lakhs tons only (2016-17) due to $46.67 \%$ of potential resources were underutilized condition. Moreover, it has significant open water and inland farming resources were $87 \%$ and $13 \%$, respectively with the inland fish production of $70.7 \%$ and $29.3 \%$ respectively, which proved that open water resources were highly contributed in inland fish production, even if considerable areas were underutilized condition while comparing to inland farming area. The study recommends that proper utilization of natural resources may increase the inland fish production of the state.

\section{Introduction}

Fish is a major source of cheap animal protein in the world but present issue is availability of fish protein at high risk for the past two decades due to the declined the fish production potential (FAO, 2008). Moreover, increasing population of our country is another reason for fish availability to poor people which may leads to unhealthy nation.
Similarly, per capita consumption of fish in Tamil Nadu was $9.8 \mathrm{~kg}$ per annum, which was lesser than World Health Organization recommended per capita consumption $(13 \mathrm{~kg}$ per annum) (MSF, 2011; Global Data Lab, 2018)). Hence, need to increase the per capita consumption of people by filling the gap between demand and supply. The enhancement of inland fisheries and aquaculture may fulfill the recommended per 
capita consumption. Moreover, culture based fisheries and aquaculture is major activities and they are commonly practiced in open water bodies of Tamil Nadu. This activity was highly depending on availability and quality fish seeds (Anon, 2012). Fish seed is the inevitable input in aquaculture. Therefore, the study was attempted to evaluate the relationship between fish seed production and inland fish production based on time series and utilization of potential of inland water bodies in Tamil Nadu.

\section{Materials and Methods}

Secondary data were collected from Hand Book of Fishery Statistics published by Government of India and State Fisheries Department. Annual average growth rate and total growth rate was calculated for inland fish production of Tamil Nadu. Additionally, linear regression was done for the study. Trend lines with time series data on fish seed production and inland fish production are fitted for forecasting purposes.

\section{Results and Discussion}

Tamil Nadu has vast inland resources with enormous land and water resources (3.83 lakh ha). Moreover, it has open water resources such as reservoirs, brackish water body, short and long seasonal tanks, which have occupied about $87 \%$ in total resources. Additionally, FFDA tanks, ponds and tanks, brackish water farming area and derelict water were available at $13 \%$ in total inland fishery resources (Table 1).

Short seasonal tank was first highly available inland fishery resources at $41.2 \%$ followed by reservoirs (16.16\%), long seasonal tanks $(15.7 \%)$, brackish water fishery area (13.3\%) and ponds and tanks (8\%). These resources were providing livelihood for 2.2 million fisher folk. Brackish water faming area and derelict water resources are available at $>1 \%$ level (Table 1).

Open water resources were highly contributed in fish production of Tamil Nadu (70.7\%) when compared to inland culture resources (29.3\%) (Table 1). However, there was higher potential area underutilized in open water sources than inland aquaculture area. Hence, the proper utilization and management of the resources may increase the fish production from the inland fishery resources.

\section{Contribution of resources in fish production}

In inland resources, $53.38 \%$ of potential natural resources were utilized for fish production while $46.62 \%$ was underutilized. Figure 1 was revealed that short seasonal tanks, FFDA tanks and brackish water farming resources were 100 percent utilized but ponds and tanks, reservoirs, long seasonal tanks, brackish water fishery and derelict water were underutilized.

In open water, short seasonal tanks were highly contributed in inland fish production at $54 \%$ followed by brackish water shrimp farming area (20.9\%), long seasonal tanks $(9.0 \%)$ brackish water fisheries (5\%), FFDA tanks $(4.95 \%)$, pond \& tanks $(3.2 \%)$ and reservoir (2\%) (Table 2$)$.

Ponds and tanks were occupied $8.3 \%$ of area but utilized only $4.84 \%$ (5000 ha) with the fish production of $3.2 \%$ in total fish production due to water crisis and the lack of management in fish culture methods. Therefore, the study was proved that efficient utilization of resources may leads to achieve the potential of $1,60,000$ tons, which was confirmed by Krishnan (2000), who reported that the potential of pond fish culture in India was 5 tons/ha but in Tamil Nadu achieved production was only 2.5-3.0 t/ha 

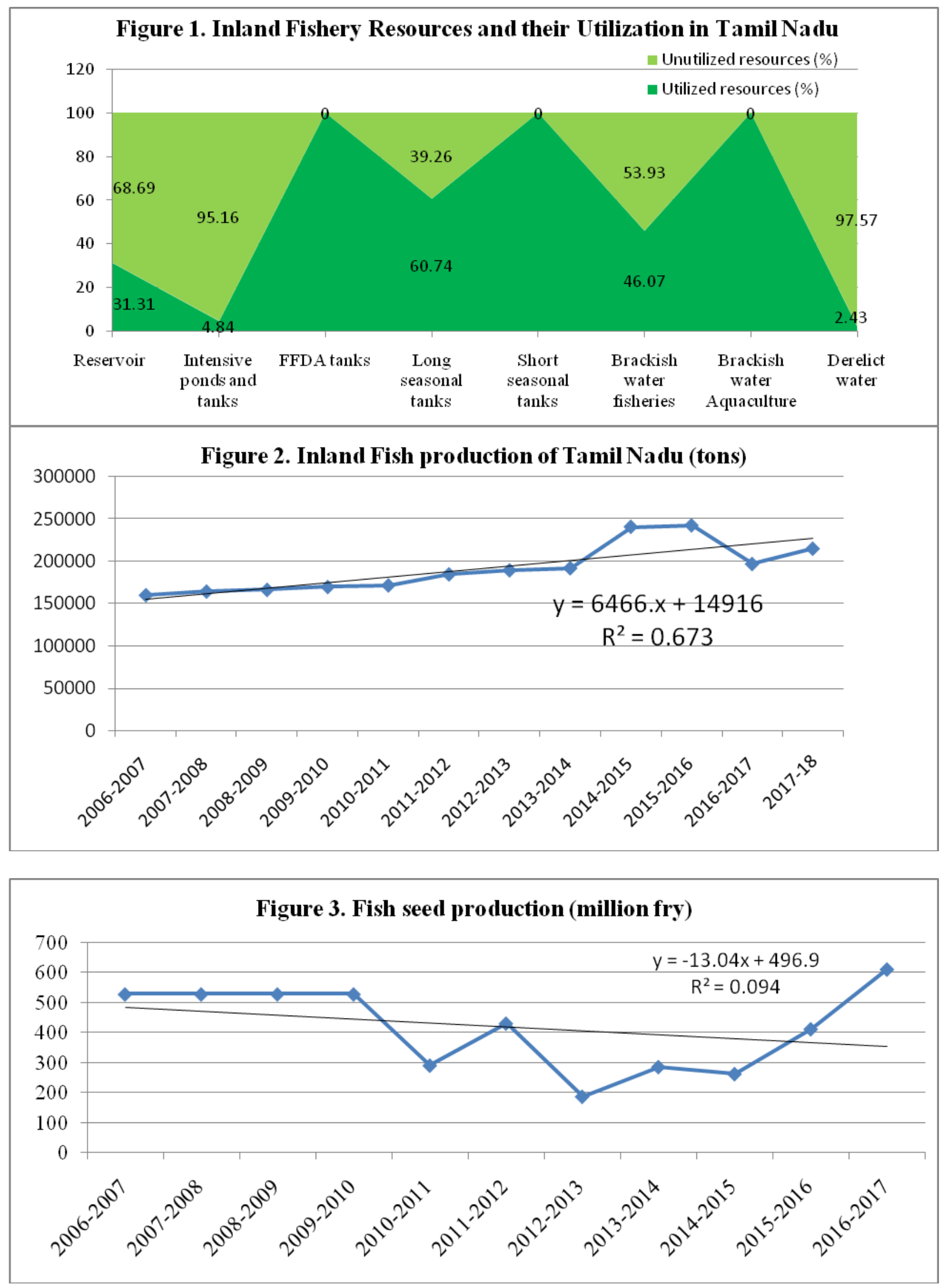


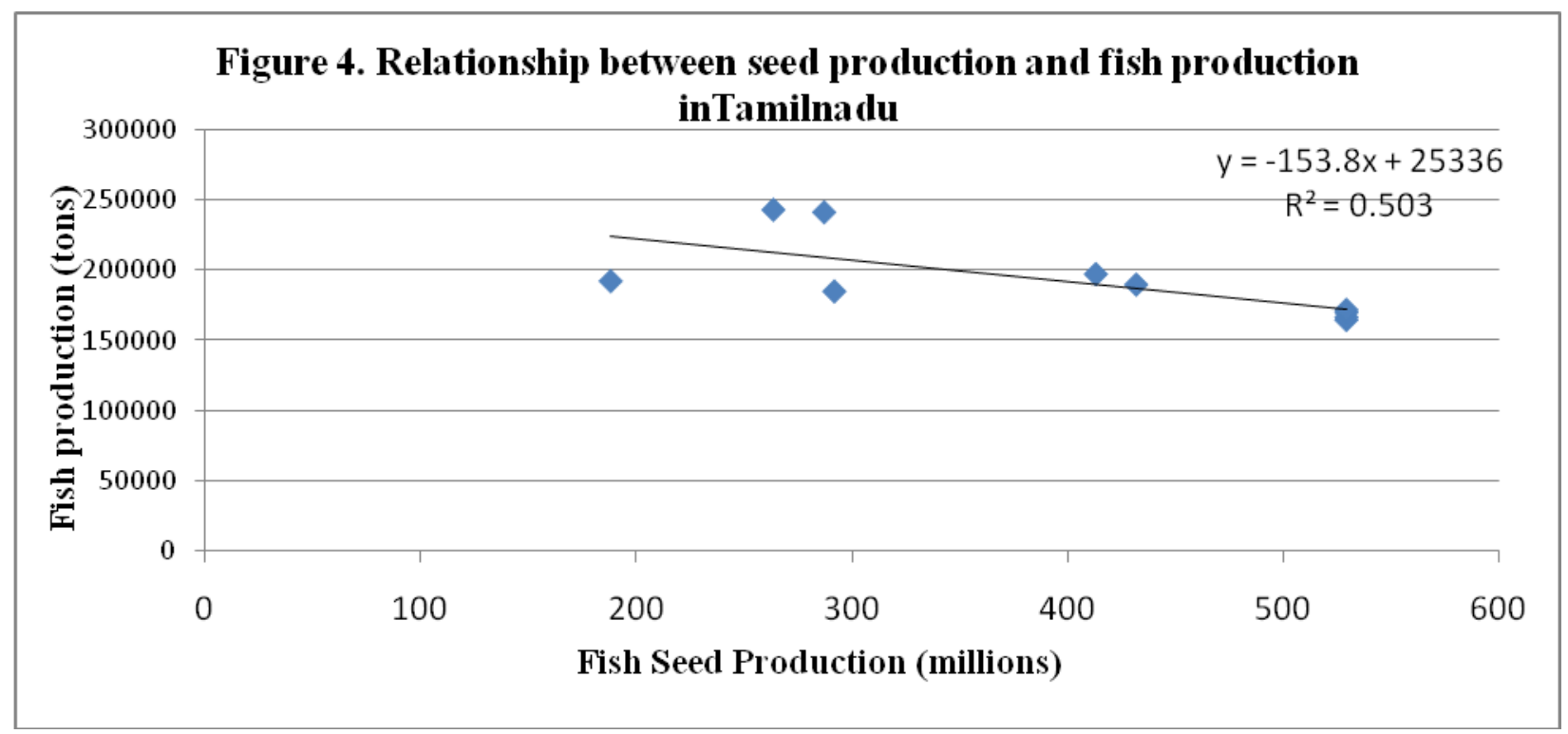

Table.1 Inland fishery resources available and production in Tamil Nadu

\begin{tabular}{|l|l|c|c|c|c|}
\hline $\begin{array}{c}\text { S. } \\
\text { No. }\end{array}$ & \multicolumn{1}{|c|}{ Resources } & $\begin{array}{c}\text { Available } \\
\text { resources (ha.) }\end{array}$ & \% & $\begin{array}{c}\text { Fish production } \\
\text { tons (2015-16) }\end{array}$ & \% \\
\hline $\mathbf{1 .}$ & Reservoir (250kg/ha) & 62,015 & 16.16 & $4,854.30$ & 2.00 \\
\hline $\mathbf{2 .}$ & $\begin{array}{l}\text { Brackish water fisheries } \\
(0.5 \mathrm{t} / \mathrm{ha})\end{array}$ & 52,719 & 13.73 & $12,144.191$ & 5.00 \\
\hline $\mathbf{3 .}$ & Short seasonal tanks & $1,58,160$ & 41.2 & $1,32,518.24$ & 54.64 \\
\hline $\mathbf{4 .}$ & $\begin{array}{l}\text { Long seasonal tanks } \\
\text { (0.5t/ha) }\end{array}$ & 60,304 & 15.72 & $21,980.161$ & 9.06 \\
\hline $\mathbf{5 .}$ & Fisheries (open water) & $\mathbf{1 7 5 , 0 3 8}$ & $\mathbf{8 7}$ & $\mathbf{3 8 , 9 7 9}$ & $\mathbf{7 0 . 7 0}$ \\
\hline $\mathbf{6 .}$ & FFDA tanks & 5,386 & 1.41 & $12,008.33$ & 4.95 \\
\hline $\mathbf{7 .}$ & $\begin{array}{l}\text { Intensive ponds and tanks } \\
\text { (5t/ha) }\end{array}$ & 32,000 & 8.34 & $7,755.33$ & 3.20 \\
\hline $\mathbf{8 .}$ & Brackish water farming & $\mathbf{6 , 2 5 0}$ & 1.62 & $50,786.27$ & 20.94 \\
\hline $\mathbf{9 .}$ & Derelict water & 7,000 & 1.82 & 512.195 & 0.21 \\
\hline $\mathbf{1 0 .}$ & Aquaculture & $\mathbf{5 0 , 6 3 6}$ & $\mathbf{1 3}$ & $\mathbf{7 1 , 0 6 2}$ & $\mathbf{2 9 . 3 0}$ \\
\hline & $\begin{array}{c}\text { Total (Fisheries and } \\
\text { Aquculture) }\end{array}$ & $\mathbf{3 , 8 3 , 8 3 4}$ & 100 & $\mathbf{2 , 4 2 , 5 5 8 . 9 5}$ & 100 \\
\hline
\end{tabular}

State Fisheries Department, 2015-16 
Table.2 Potential of inland water resources and its status of utilization

\begin{tabular}{|l|l|c|c|c|}
\hline $\begin{array}{c}\text { S. } \\
\text { No. }\end{array}$ & \multicolumn{1}{|c|}{ Resources } & $\begin{array}{c}\text { Potential of inland } \\
\text { fisheries } \mathbf{( T )}\end{array}$ & $\begin{array}{c}\text { Utilized } \\
\text { potential } \\
\mathbf{( \% )}\end{array}$ & $\begin{array}{c}\text { Unutilized } \\
\text { potential } \\
\mathbf{( \% )}\end{array}$ \\
\hline $\mathbf{1 .}$ & Reservoir (250kg/ha) & 15,504 & 31.31 & 68.69 \\
\hline $\mathbf{2 .}$ & $\begin{array}{l}\text { Intensive ponds and tanks } \\
\text { (5t/ha) }\end{array}$ & $1,60,000$ & 4.84 & 95.16 \\
\hline 3. & FFDA tanks & 12,008 & 100 & 0 \\
\hline $\mathbf{4 .}$ & Long seasonal tanks (0.5t/ha) & $36,182.5$ & 60.74 & 39.26 \\
\hline $\mathbf{5 .}$ & Short seasonal tanks & $1,32,518$ & 100 & 0 \\
\hline 6. & Brackish water area (0.5-3 t/ha) & $26,359.5$ & 46.07 & 53.93 \\
\hline 7. & $\begin{array}{l}\text { Brackish water area under } \\
\text { culture }\end{array}$ & 50,786 & 100 & 0 \\
\hline $\mathbf{8 .}$ & Derelict water (3t/ha) & 21,000 & 2.43 & 97.57 \\
\hline & Total & $4,54,358$ & 53.38 & 46.62 \\
\hline
\end{tabular}

State Fisheries Department, 2015-16

Table.3 Inland seed and fish production of Tamil Nadu

\begin{tabular}{|l|l|c|c|c|c|}
\hline S. No. & \multicolumn{1}{|c|}{ Year } & $\begin{array}{c}\text { Fish seed } \\
\text { production }(\mathbf{m i l l i o n} \\
\mathbf{f r y}\end{array}$ & $\begin{array}{c}\text { Growth rate } \\
\mathbf{( \% )}\end{array}$ & $\begin{array}{c}\text { Fish production } \\
\mathbf{( K g})\end{array}$ & $\begin{array}{c}\text { Growth rate } \\
(\mathbf{\%})\end{array}$ \\
\hline $\mathbf{1 .}$ & $2006-2007$ & 529.28 & - & 160172 & - \\
\hline $\mathbf{2 .}$ & $2007-2008$ & 529.28 & 0 & 164504 & -2.70 \\
\hline $\mathbf{3 .}$ & $2008-2009$ & 529.28 & 0 & 166456 & 1.18 \\
\hline $\mathbf{4 .}$ & $2009-2010$ & 529.28 & 0 & 169791 & 2.00 \\
\hline $\mathbf{5 .}$ & $2010-2011$ & 291.82 & -44.86 & 171705 & 1.12 \\
\hline $\mathbf{6 .}$ & $2011-2012$ & 431.84 & 47.98 & 184753 & 7.6 \\
\hline $\mathbf{7 .}$ & $2012-2013$ & 188.2 & -56.41 & 189563 & 2.60 \\
\hline $\mathbf{8 .}$ & $2013-2014$ & 287.15 & 52.57 & 192029 & 1.30 \\
\hline $\mathbf{9 .}$ & $2014-2015$ & 263.58 & 8.20 & 240862 & 25.43 \\
\hline $\mathbf{1 0 .}$ & $2015-2016$ & 413.1 & 56.72 & 242559 & 0.70 \\
\hline $\mathbf{1 1 .}$ & $2016-2017$ & 612.27 & 48.21 & 197000 & -18.78 \\
\hline & Average Growth Rate & $\mathbf{1 0 . 2 1}$ & & $\mathbf{1 . 8 5}$ \\
\hline
\end{tabular}

Handbook of Fisheries statistics, 2014 (Govt. of India and Tamil Nadu)

Tamil Nadu has brackish water spread area about 56000 ha, in which $11 \%$ (6250 ha) area was utilized for aquaculture purpose. Since, it was occupied $1.6 \%$ in total inland fishery resources but it was achieved $20 \%$ $(50,786.27 \mathrm{t})$ in total inland fish production. 
Fish Farmer Development Agency (FFDA) was taken $1.41 \%$ of inland area under its control and developed aquaculture practices by providing subsidy to the fish farmers and achieved the fish production $4.95 \%$ in total inland fish production.

Similarly, short seasonal tank and brackish water aquaculture farms also achieved their maximum production.

Reservoirs are one of the bulk inland resources of our state. They were contributing $2 \%$ in total inland fish production, while it is available at $16.6 \%$ in total inland fishery resources. Moreover, $>68 \%$ of potential was underutilized condition. So, there was huge potential to improve the inland fish production further (Figure 1).

\section{Growth in seed and fish production}

The secondary data for the period 2007-08 to 2017-18 for fish seed and fish production were analyzed to visualize the growth and trend (Table 3). It was found that during last eleven years, Average Annual Growth Rate (AAGR) in fish production was 1.87 percent whereas in growth of seed production was 10.21 percent. Growth rate of seed production was higher than the fish production in Tamil Nadu. Similar result was reported by Maurya et al., (2018) that higher growth rate was observed in seed production $(7.67 \%)$ than fish production was (7.56\%) in Uttar Pradesh (Fig. 2).

\section{Trend in seed and fish production}

Tamil Nadu has constant growth in fish production for last eleven years. Inland fish production data of Tamil Nadu were fitted in the linear regression chart which shows that positive production in every year, which was evidenced by $R^{2}$ value 0.678 , while fish seed production has no constant growth in every year, which was evidenced by $\mathrm{R}^{2}$ value 0.094 . Similar result was reported by Mourya et al., (2018) in the state of Uttar Pradesh.

\section{Relationship between fish seed production and fish production}

The time series data on fish seed and fish production from 2009-10 to 2016-17 was taken further analyzed to explore the relationship between seed and fish production of the state. The obtained result is presented in figure 3 . The next year fish production data was taken for the corresponding previous year seed production data, as the stocked seeds require at least 8-12 months to grow into marketable size (Chrispin et al., 2016). It was observed from figure 4 that there was weak positive relationship was found between seed and fish production in Tamil Nadu, which was confirmed by $\mathrm{R}^{2}$ value 0.503 . However, positive $\mathrm{R}^{2}$ value was proved that fish production was completely depending on seed production of the state. Similar relationship was reported in the state of West Bengal and North Eastern States (Ghosh et al., 2017, Upadhyay et al., 2012).

Tamil Nadu is blessed with enormous fisheries and aquaculture resources (3.83 lakh ha.) (Table 1). Still only $53.38 \%$ of total inland fishery resources were utilized for fish production and remaining $46.62 \%$ resources were reported to be unutilized. Short seasonal tanks, FFDA tanks and brackish water farming area were utilized at $100 \%$, while other resources were underutilized. Fish production of fisheries (open water) resources was high when compared to aquaculture resources. However, still there was huge potential of fisheries resources were underutilized condition such as reservoirs (68.69\%), brackish water fisheries $(53.93 \%)$ and long seasonal tanks (39.26\%). This result proved that growth rate of fish production and seed production in Tamil Nadu was 
increasing year by year. Fish production trend was positively increasing, while seed production has negative trend in Tamil Nadu. However, the study proved that fish production was completely depending on seed production of the state.

\section{References}

Anon. 2014. Handbook on Fisheries Statistics.

Chrispin, C.L., Ananthan, P.S., Sugunan, V.V., Ramasubramanian, V., Panikkar, P., and Landge, A.T., 2016. Fisheries and management status of Pechiparai Reservoir in Tamil Nadu. Curr. World Environ. 11(1): 233-242.

FAO, 2008. The State of World Fisheries and Aquaculture. Fisheries and Aquaculture Department, Food and Agriculture Organization of the United Nations, Rome, Italy.

Ghosh, A., Mohapatra, B.K., and Roy, A.K, 2017. Relationship between Fish Seed Production and Inland Fish Production of West Bengal, India. SM J Biometrics Biostat. 2(2): 1013.
Global Data Lab, 2018. Institute for Management Research, Radboud University. Retrieved 25 September 2018

Katiha Pradeep K, 2000. Freshwater Aquaculture in India: Status, Potential and Constraints. In Krishnan, M. and Birthal, P.S. (eds) Aquacultural Development of India: Problems and Prospects.

Maurya, A.K., Upadhyay, A.D., Laxmi Prasad and Shakila Khan, 2018. Trend analysis of fish production in Uttar Pradesh, India. Journal of Entomology and Zoological Studies. 6(4): 180-184.

MFS, 2011. Manual of fishery statistics. Central Statistics office, Ministry of Statistics and Programme Implementation. New Delhi, Government of India. 84 pp.

Tamil Nadu State Fisheries Department, Published and unpublished data, 201516.

Upadhyay, A. D., Roy, A. K and Jumli Karga, 2012. Exploratory Data Analysis Approach with Fish and Seed Production in Arunanchal Pradesh. Keanean Journal of Science.

\section{How to cite this article:}

Gowsalya, T., V. Kanaga and Sundaramoorthy, B. 2019. Trend Analysis of Inland Fish Production of Tamil Nadu with Special References to Resources and Seed Production. Int.J.Curr.Microbiol.App.Sci. 8(08): 101-107. doi: https://doi.org/10.20546/ijcmas.2019.808.012 